\title{
Onboard rearing attempts for the Japanese eel leptocephali using POM-enriched water collected in the Western North Pacific
}

\author{
Seinen Chow ${ }^{1, *}$, Hiroaki Kurogi ${ }^{2}$, Satoshi Watanabe ${ }^{3}$, Hiroyuki Matsunari ${ }^{3}$, Ryusuke Sudo $^{3}$, \\ Kazuharu Nomura $^{3}$, Hideki Tanaka ${ }^{3}$, Hirofumi Furuita ${ }^{3}$, Atsushi Nishimoto ${ }^{1}$, Masato Higuchi ${ }^{4}$, \\ Tadao Jinbo ${ }^{4}$ and Tsutomu Tomoda ${ }^{4}$ \\ ${ }^{1}$ National Research Institute of Fisheries Science, Japan Fisheries Research and Education Agency, 2-12-4 Fukuura, \\ Yokohama, Kanagawa 236-8648, Japan \\ 2 Yokosuka Station, National Research Institute of Fisheries Science, Japan Fisheries Research and Education Agency, \\ 6-3-1 Nagai, Kanagawa 238-0316, Japan \\ ${ }^{3}$ Nansei Station, National Research Institute of Aquaculture, Japan Fisheries Research and Education Agency, \\ 422-1 Nakatsu-Hamaura, Mie 515-0193, Japan \\ ${ }^{4}$ Shibushi Station, National Research Institute of Aquaculture, Japan Fisheries Research and Education Agency, \\ 205 Natsui, Shibushi, Kagoshima 899-7101, Japan
}

Received 23 June 2017 / Received in final form 18 August 2017 / Accepted 16 September 2017

Handling Editor: Catarina Vinagre

\begin{abstract}
Hatchery produced leptocephalus larvae of the Japanese eel (Anguilla japonica) were reared on a research vessel and fed natural particulate organic matter (POM) collected in the Western North Pacific. A small net ( $36 \mathrm{~cm}$ diameter, $60 \mu \mathrm{m}$ mesh) was vertically towed from $200 \mathrm{~m}$ depth to surface in 2013 , and POM-enriched water (POMEW) filtered through $350 \mu \mathrm{m}$ mesh was fed to the leptocephali for 11 days. Although the swollen gut corroborated the active ingestion of POM by the leptocephali, low survival rate and heavily melanized gut followed by necrosis in the mid-hindgut region of the leptocephali were observed. A large net ( $1.14 \mathrm{~m}$ diameter, $30 \mu \mathrm{m}$ mesh) was used in 2014 and 2015 , which was horizontally drifted subsurface (100-175 m). POMEWs filtered through 53 or $25 \mu \mathrm{m}$ meshes were fed to the leptocephali for 518 days. Neither melanized gut nor necrosis occurred, but considerably low survival rate and little growth comparable with that in a starved condition were observed. No apparent shift in stable carbon and nitrogen isotope ratios was observed in the reared leptocephali. These indicated that the ingested POMs were not assimilated by the leptocephali and suggested that smaller particles may be important for the leptocephali.
\end{abstract}

Keywords: Anguilla japonica / Leptocephalus / Particulate organic matter / Natural diet / On board rearing / Stable isotope

\section{Introduction}

Marine and freshwater eels of the Anguilliformes are known to have peculiar transparent leaf-like larvae called leptocephali (Miller, 2009). Natural diets of the eel leptocephali have not been identified. Earlier studies reported poorly differentiated leptocephalus gut containing no identifiable food material (Hulet, 1978). Hulet (1978) suggested that dissolved organic compounds may be directly absorbed through the epidermis, and also hypothesized that the leptocephali may utilize the sharp teeth to puncture other organisms and to swallow the body fluid. However, a later histological investigation indicated the

\footnotetext{
*Corresponding author: chow@affrc.go.jp
}

alimentary tract of the Japanese eel (Anguilla japonica) leptocephali was functional in uptaking and digesting intact macromolecules (Otake, 1996). Mochioka et al. (1993) observed that the wild-caught leptocephali of the pike conger Muraenesox cinereus and the conger eel Conger myriaster were not attracted by living zooplankton such as copepod larvae and ctenophore but actively ingested squid paste. Butts et al. (2016) fed frozenthawed Sargasso planktons to the European eel (A. anguilla) but observed no ingestion by the larvae. On the other hand, Masuda et al. (2010) reported that cow's milk was ingested and utilized by reared Japanese eel leptocephali. Using the slurry-type artificial food containing shark egg yolk, Tanaka et al. (2003) first succeeded to grow artificially hatched leptocephali of the Japanese eel to the glass eel stage. 
Table 1. Information of the Japanese eel, Anguilla japonica leptocephali used for feeding experiment on board.

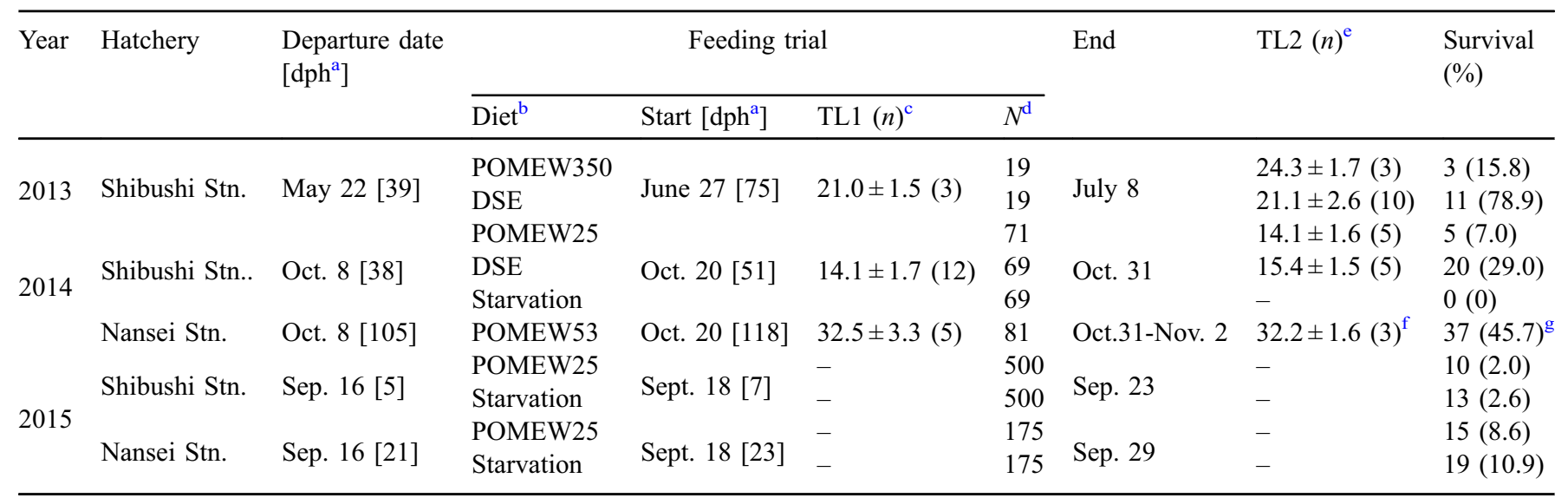

a Days post hatch.

b POM-enriched water samples (POMEW) filtered through 350, 53 and $25 \mu \mathrm{m}$ meshes, and defatted shark egg-based diet (DSE).

c Average total length $(\mathrm{mm})$ and number of individuals (parenthesis) sub-sampled at the onset of the feeding experiment.

${ }^{\mathrm{d}}$ Initial number of leptocephali.

e Average total length ( $\mathrm{mm}$ ) and number of individuals (parenthesis) examined at the end of the feeding experiment.

$\mathrm{f}$ Total length was measured at November 1 and 2 .

Amorphous materials appear to be the major gut contents in wild leptocephali, while fecal pellets of zooplankton, larvacean houses, appendicularians, and aloricate protozoa have been also observed in much smaller amounts in many anguillid leptocephali (Otake et al., 1993; Mochioka and Iwamizu, 1996; Govoni, 2010; Miller et al., 2011; Tomoda et al., 2017). Thus, accumulating information on the gut content and low trophic position of the eel leptocephali (Otake et al., 1993; Mochioka and Iwamizu, 1996; Kimura and Tsukamoto, 2006; Chow et al., 2010; Miller et al., 2011, 2013; Miyazaki et al., 2011; Tomoda et al., 2017) suggest that particulate organic matter (POM) including marine snow may be the natural diet for eel leptocephali.

The spawning area for the Japanese eel has been determined to be located at the southern part of the West Mariana Ridge (Tsukamoto, 2006; Chow et al., 2009; Kurogi et al., 2011; Tsukamoto et al., 2011), and the larval transport via the North Equatorial Current in the Western North Pacific has been well documented (Tsukamoto, 2006). In order to evaluate value of POM as a feed for the eel leptocephali, we attempted rearing the Japanese eel leptocephali on a research vessel with POM-enriched subsurface sea water collected in the Western North Pacific.

\section{Materials and methods}

\subsection{Diet-switch experiment in the laboratory}

This experiment was performed to investigate assimilation rate by the leptocephali. Based on the previous investigations (Ohta et al., 1996; Kagawa et al., 1997, 2013; Furuita et al., 2014), female and male adult eels were induced to maturity using hormonal treatment at the Nansei Station of the National Research Institute of Aquaculture (NRIA), Japan Fisheries Research and Education Agency. Fertilized eggs were obtained from spontaneously spawned eggs, and hatched leptocephali were transferred to the Shibushi Station of NRIA at 5 days post hatch (dph), where ca. 400 leptocephali were kept in a $10 \mathrm{~L}$ tank. Rearing system followed Tanaka et al. (2003) and Furuita et al. (2014). Temperature and exchange rate of filtered sea water were maintained at $23-24^{\circ} \mathrm{C}$ and $0.5-0.8 \mathrm{~L} \mathrm{~m}^{-1}$, respectively. The experimental diets were offered at $6 \mathrm{dph}$. Two slurry-type artificial diets (DSE and DHY) were prepared, of which DSE was based on defatted shark egg and DHY was based on defatted hen egg yolk (see Furuita et al., 2014). Six to seven $\mathrm{mL}$ of the diets were fed four to five times a day. The leptocephali were initially fed DSE from 6 to $28 \mathrm{dph}$, and DHY from $29 \mathrm{dph}$ until the end of experiment $(50 \mathrm{dph})$. Dead individuals were removed every day. To control the larval density and to monitor the growth, 12-18 leptocephali were periodically sampled in the morning before the first feeding for the total length measurements. Among leptocephali sampled after the diet-switch, three lots (four to six individuals were pooled per lot) at each sampling day were used for stable isotope analysis.

\subsection{On board rearing experiment}

Leptocephali of the Japanese eel produced as above mentioned in the Nansei and Shibushi Stations were transferred to the research vessel RV Kaiyo-Maru, Fisheries Agency of Japan, on the day or one day before departure, where the same rearing system used for the laboratory experiment was built. The rearing water was prepared by filtering the surface seawater through $1 \mu \mathrm{m}$ cartridge filters (TCW-1N-PPD; Advantec Toyo Kaisha, Ltd., Tokyo, Japan). Information on the leptocephali and rearing scheme are summarized in Table 1. DSE was fed to the leptocephali until POM samples became available.

\subsection{POM samples}

Collection locations for POM samples are shown in Figure 1. CMS (coastal mesoplankton sampler) net $(36 \mathrm{~cm}$ 


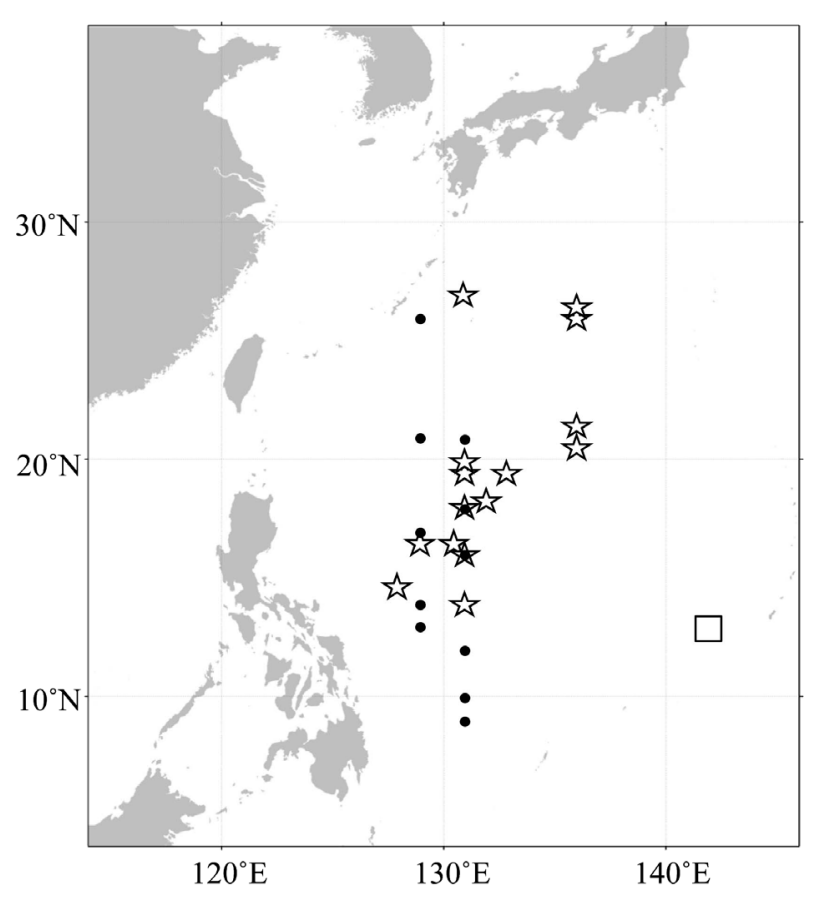

Fig. 1. Map showing collection localities for POMEW samples in 2013 (square), 2014 (closed circle) and 2015 (open star).

diameter mouth opening, $2 \mathrm{~m}$ long, $60 \mu \mathrm{m}$ mesh) (Itoh and Mochioka, 2005) with a $200 \mathrm{~mL}$ cod end bottle was used in 2013 and supplementarily in 2015. MS (marine snow) net ( $1.14 \mathrm{~m}$ diameter mouth opening, $2.6 \mathrm{~m}$ long, $30 \mu \mathrm{m}$ mesh) (Tomoda et al., 2017) with a $5 \mathrm{~L}$ cod end bottle was used in 2014 and 2015. The location and depth of POM sampling were varied, since the main purpose of the research cruise was plankton survey and the weather conditions affected the handling of net especially for the MS. The CMS net was vertically towed from $200 \mathrm{~m}$ depth to surface at $30 \mathrm{~cm} \mathrm{~s}^{-1}$. The MS net was horizontally towed at $100-175 \mathrm{~m}$ depth for $30 \mathrm{~min}$ to $1 \mathrm{~h}$ with the vessel drifting on the sea surface. POM-enriched water (POMEW) samples collected in 2013 were filtered through $350 \mu \mathrm{m}$ mesh and the filtrate was fed to the leptocephali. POMEWs collected in 2014 and 2015 were pre-filtered through 300,150 and $90 \mu \mathrm{m}$ meshes. These prefiltered POMEWs were further filtered through 53 and $25 \mu \mathrm{m}$ meshes, and the filtrates were fed to the leptocephali.

\subsection{Stable isotope analysis}

The POMEW samples filtered with GF/F glass microfiber filter $(0.7 \mu \mathrm{m})$, reared leptocephali and experimental diets (DSE and DHY) were lyophilized and ground into a fine powder, which were then defatted using 1:1 chloroformmethanol solution $(\mathrm{v} / \mathrm{v})$. The defatted samples were oven-dried and sample aliquots were placed in tin containers. The carbon and nitrogen stable isotope ratios $\left(\delta^{13} \mathrm{C}\right.$ and $\left.\delta^{15} \mathrm{~N}\right)$ were analyzed using an elemental analyzer (Vario Micro Cube, Elementar Japan) coupled with an isotope ratio mass spectrometer (IsoPrime100, Isoprime). The isotope ratios were expressed as per mil (\%o) deviation from international standard (i.e. the Vienna Pee Dee Belemnite for carbon and atmospheric $\mathrm{N}_{2}$ for nitrogen $)$, in which $\delta^{13} \mathrm{C}$ or $\delta^{15} \mathrm{~N}=\left(R_{\text {sample }} /\right.$
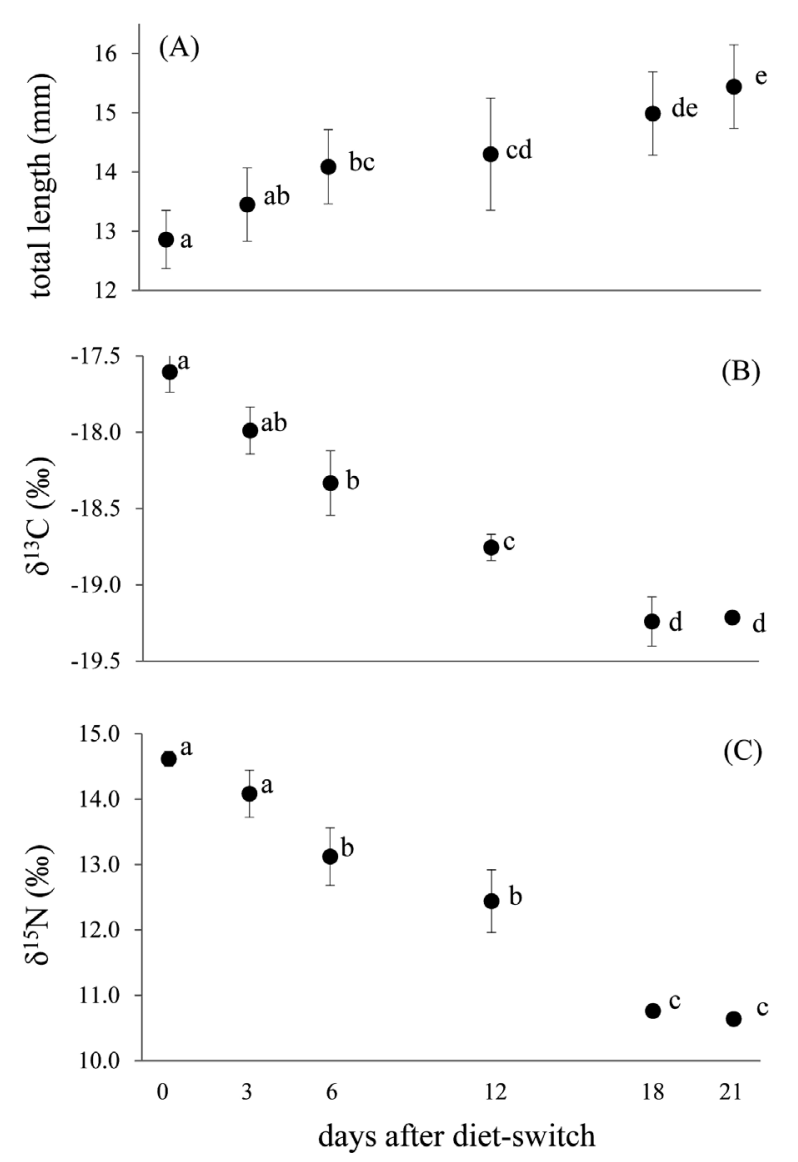

Fig. 2. Trajectories of total length (A), $\delta^{13} \mathrm{C}(\mathrm{B})$ and $\delta^{15} \mathrm{~N}(\mathrm{C})$ in leptocephali after diet-switch. Analysis of variance with Tukey-test was performed, and mean values carrying different alphabets differ significantly $(P<0.05)$.

$\left.R_{\text {standard }}-1\right) \times 1000$, where $R$ is ${ }^{13} \mathrm{C} /{ }^{12} \mathrm{C}$ or ${ }^{15} \mathrm{~N} /{ }^{14} \mathrm{~N}$. Using data from the diet-switch experiment, half-life that the isotopic composition of the tissue reaches to a midpoint between the initial and asymptotic values was calculated using exponential model of Hobson and Clark (1992).

\section{Results}

\subsection{Diet-switch experiment in the laboratory}

The mean stable isotope ratios $( \pm \mathrm{SD})$ of DSE were $-17.9 \pm 0.1 \%$ for $\delta^{13} \mathrm{C}$ and $13.1 \pm 0.1 \%$ for $\delta^{15} \mathrm{~N}$, and those of DHY were $-18.5 \pm 0.3 \%$ for $\delta^{13} \mathrm{C}$ and $4.4 \pm 0.1 \%$ for $\delta^{15} \mathrm{~N}$. Trajectories of growth and mean stable isotope ratios of leptocephali after diet-switch are shown in Figure 2. The mean total length of the leptocephali at 6 days after diet-switch became significantly larger than that at 0 day (Fig. 2A). The mean stable isotope ratios of the leptocephali on the day of diet-switch were $-17.6 \pm 0.1 \%$ for $\delta^{13} \mathrm{C}$ and $14.6 \pm 0.1 \%$ for $\delta^{15} \mathrm{~N}$. Both isotope ratios of the leptocephali gradually decreased and those at 6 days after the diet-switch became significantly lower than those at 0 day (Fig. $2 \mathrm{~B}$ and C). No significant difference was observed in both isotope ratios between 18 and 21 days after the diet-switch. Given that the both isotope ratios reach asymptotic at 18 days after the dietswitch, half-life was estimated to be 4.6 days. 


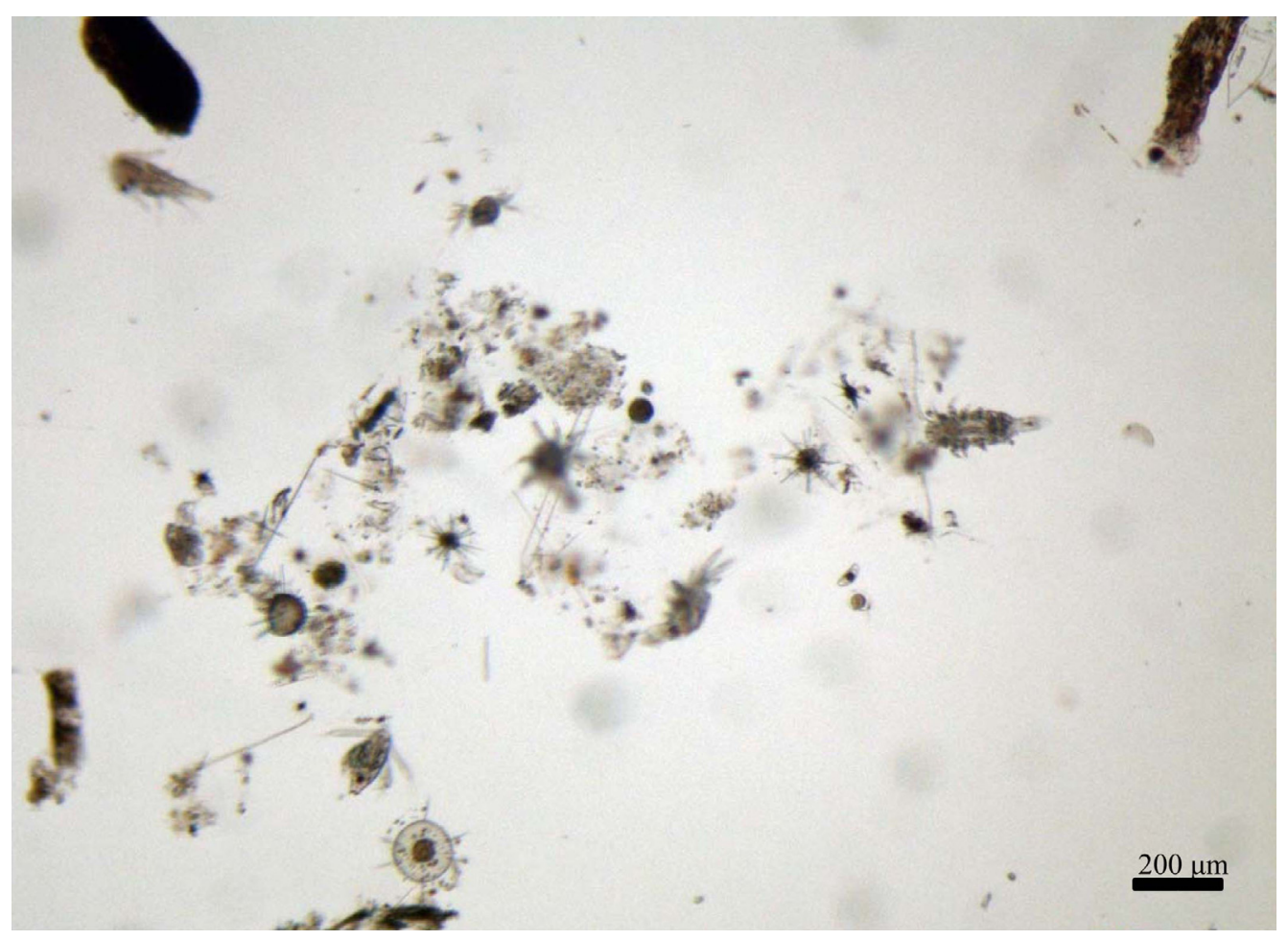

Fig. 3. Zoo- and phytoplanktons and amorphous materials observed in POMEW sample filtered through $350 \mu \mathrm{m}$ mesh in 2013 cruise.
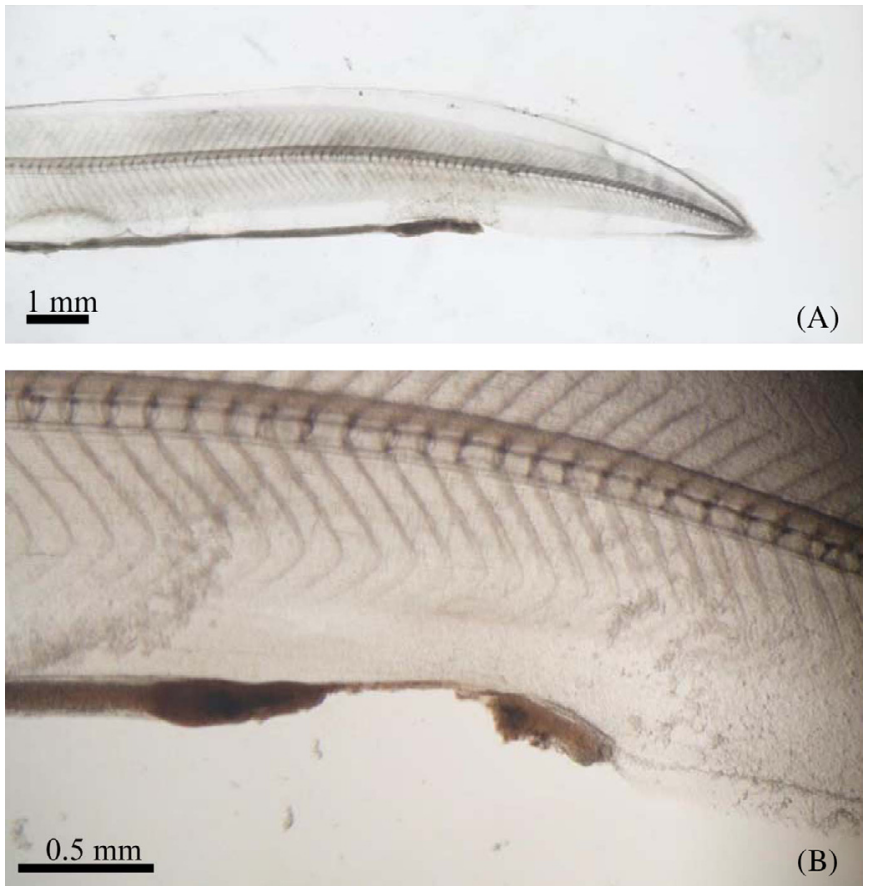

Fig. 4. Melanised gut (A) and necrosis of abdominal region (B) of leptocephali observed in POMEW feeding experiment in 2013.

\subsection{Onboard rearing experiment}

The POMEW samples used for feeding in 2013 were collected in narrow area (Fig. 1, open squares). The amount of POMEW sample per one CMS net cast was ca. $300 \mathrm{~mL}$ (including rinsing water), and two to four casts were performed at one site. The POMEW sample was filtered through $350 \mu \mathrm{m}$ mesh (POMEW350) before feeding to the leptocephali and analyzed for the stable isotope ratios. Age of leptocephali was $75 \mathrm{dph}$ at the onset of POMEW350 feeding, and the mean total length of sub-sampled leptocephali was $21.0 \pm 1.5 \mathrm{~mm}(n=3)$ (Tab. 1). Two tanks contained 19 leptocephali each, and DSE ( $5 \mathrm{~mL}$, four times a day) was fed to one and POMEW350 $(500 \mathrm{~mL}$, two times a day) to the other. Water supply was ceased for $15 \mathrm{~min}$ during the DSE feeding and for $3 \mathrm{~h}$ during the POMEW350 feeding. Many zoo- and phytoplanktons were observed in the POMEW350 (Fig. 3). Swollen guts were observed in the leptocephali in both tanks within $1 \mathrm{~h}$ after feeding, indicating active ingestion. Melanized guts were observed in several leptocephali in the POMEW350 feeding (Fig. 4A), and necrosis in the mid-hindgut region began to be observed from 5 days after the onset of feeding (Fig. 4B). Leptocephali showing necrosis were assumed to be dying and sampled for stable isotope analysis. Only three leptocephali $(15.8 \%)$ survived to the final day (11th day) in the POMEW350 feeding treatment, in which no symptom of necrosis was observed, and the mean total length was $24.3 \pm 1.7 \mathrm{~mm}$ (Tab. 1). Higher survival $(78.9 \%)$ and no necrosis were observed in the DSE feeding group, and the mean total length was $21.1 \pm 2.6 \mathrm{~mm}(n=11)$ on the 11 th day (Tab. 1). There was no significant difference in the mean total length between POMEW350 and DSE feeding groups. Stable isotope ratios of DSE, POMEW and leptocephali are shown in Figure 5. The $\delta{ }^{15} \mathrm{~N}$ of POMEW350 (3.9 $\pm 1.1 \%$ ) was depleted than that of DSE $(12.1 \pm 0.2 \%$ ) by $8.2 \%$. The correlations between isotope ratios of the leptocephali and feeding period were not significant $\left(r^{2}<0.03, P>0.1\right)$ in the POMEW350 feeding group. No apparent difference was observed in the 

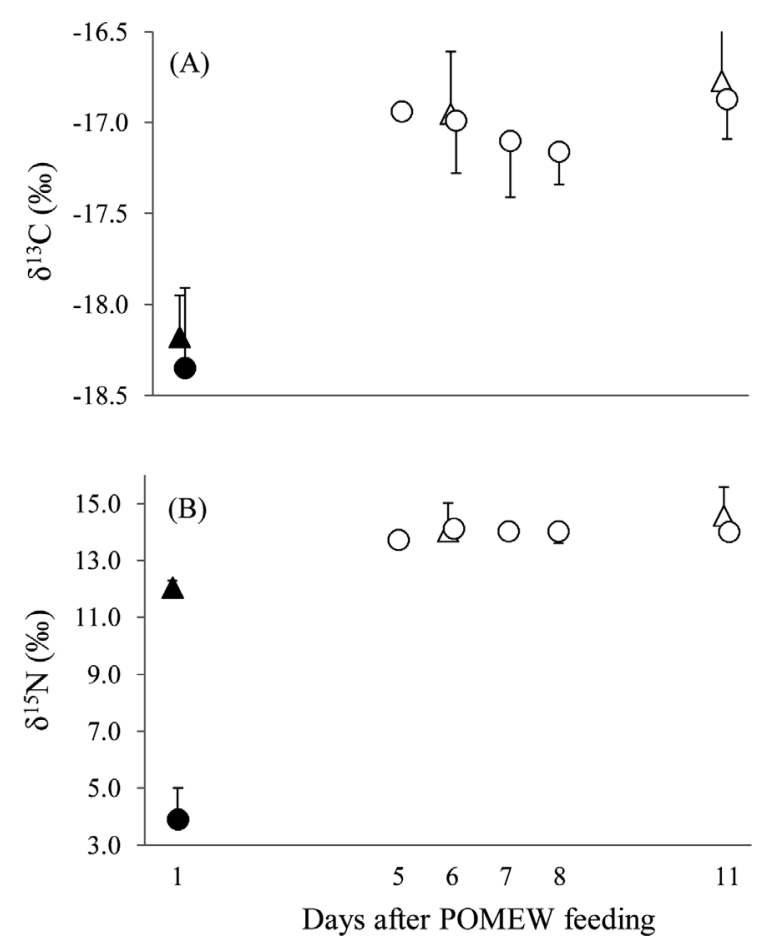

Fig. 5. Trajectories of $\delta^{13} \mathrm{C}(\mathrm{A})$ and $\delta^{15} \mathrm{~N}(\mathrm{~B})$ in leptocephali fed DSE (open triangle) and POMEW (open circle) in 2013. Stable isotope ratios of DSE and POMEW are shown by closed triangle and closed circle, respectively.

$\delta^{15} \mathrm{~N}$ values between leptocephali fed POMEW350 and DSE (14.0 $\pm 0.3 \%$ and $14.2 \pm 0.5 \%$, respectively) (Mann-Whitney $U$ test, $P>0.07$ ).

POMEW samples in 2014 were collected in wide area (Fig. 1, closed circles). Of $5 \mathrm{~L}$ volume of POMEW obtained at one MS net cast, $3 \mathrm{~L}$ was filtered and used for feeding and $1 \mathrm{~L}$ for stable isotope analysis. Ages of two size groups of leptocephali at onset of experiment were 51 and $118 \mathrm{dph}$ (Tab. 1). Smaller leptocephali were used for POMEW25 (filtered through $25 \mu \mathrm{m}$ mesh) feeding, DSE feeding and starvation groups, $(n=71,69$ and 69 , respectively), and POMEW53 (filtered through $53 \mu \mathrm{m}$ mesh) was fed to larger leptocephali $(n=81)$ (Tab. 1). Large zoo- and phytoplanktons observed in POMEW350 during 2013 cruise did not exist in POMEW25 and POMEW53, while small amount of amorphous materials and small spherical particles $(\sim 20 \mu \mathrm{m})$ were observed (see Tomoda et al., 2017). Neither melanized gut nor necrosis in the leptocephali was observed, but unidentified whitening disease caused low survival for all rearing lots. At the end of the experiment for smaller leptocephali (11th day), no survival was observed under starved condition and survival rates in POMEW25 (7.0\%) feeding groups were much lower than that in DSE feeding group (29.0\%). No growth was observed in POMEW25. Not significant but mean total length $(15.4 \pm 1.5 \mathrm{~mm})$ in DSE feeding at 11th day was slightly larger than that $(14.1 \pm 1.7 \mathrm{~mm})$ at 0 day. Although the survival rate of larger leptocephali fed POMEW53 was high (45.7\%), little growth was observed. The mean total length on the final day in DSE feeding was slightly larger than that at the onset but difference was not significant. Stable isotope ratios of smaller leptocephali at the onset of the experiment were $-17.1 \pm 0.1 \%$ o for $\delta^{13} \mathrm{C}$ and $15.0 \pm 0.2 \%$ for $\delta^{15} \mathrm{~N}$, and those of larger leptocephali were $-19.3 \pm 0.6 \%$ for $\delta^{13} \mathrm{C}$ and $10.1 \pm 0.8 \%$ for $\delta^{15} \mathrm{~N}$. Different formulations of DSE between Shibushi and Nansei Stations reflected isotopic differences between smaller and larger leptocephali. Stable isotope ratios on the final day of the experiment were $-18.3 \%$ for $\delta^{13} \mathrm{C}$ and $14.3 \%$ for $\delta^{15} \mathrm{~N}$ in smaller leptocephali ( $n=1$, five individuals pooled). Some of larger leptocephali were reared by $136 \mathrm{dph}$, and the stable isotope ratios were $-19.0 \pm 0.4 \%$ for $\delta^{13} \mathrm{C}$ and $10.0 \pm 0.6 \%$ for $\delta^{15} \mathrm{~N}(n=3)$. These values were not notably different from those at the onset. The $\delta^{13} \mathrm{C}$ of POMEW53 and POMEW25 ranged from $-21.9 \%$ to $-20.9 \%$ with the average of $-21.4 \pm 0.4 \%$ and from $-22.0 \%$ to $-20.9 \%$ with the average of $-21.4 \pm 0.4 \%$, respectively (Fig. $6 \mathrm{~A}$ ). The $\delta^{15} \mathrm{~N}$ of these ranged from $1.5 \%$ to $4.9 \%$ with the average of $2.8 \pm 1.0 \%$ and from $1.2 \%$ to $6.2 \%$ with the average of $3.2 \pm 1.4 \%$, respectively (Fig. 6B). The stable isotope ratios of POMEW53 and POMEW25 were considerably depleted than those in the reared leptocephali.

POMEW samples in 2015 were collected in wide area (Fig. 1, open stars). Ages of two size groups of leptocephali at the onset of the experiment were 7 and $23 \mathrm{dph}$, and the initial numbers of leptocephali used for the experiment were 500 and 175 , respectively (Tab. 1). Drastic mortality was observed in the small size group, in which the survival rates at 5 days after the onset of the experiment for POMEW25 feeding and starvation groups were $2.6 \%$ and $2.0 \%$, respectively, and the experiment was ceased. The larger size leptocephali lived longer, and the survival rates at 11 days after the onset of the experiment were $8.6 \%$ for POMEW25 feeding group and $10.9 \%$ for starvation group. Stable isotope ratios of the leptocephali were not analyzed, while those of POMEW25 ranged from $-23.0 \%$ to $-20.5 \%$ with the average of $-21.7 \pm 0.8 \%$ for $\delta^{13} \mathrm{C}$ (Fig. $6 \mathrm{C}$ ) and ranged from $0.0 \%$ to $2.7 \%$ with the average of $1.2 \pm 0.8 \%$ for $\delta^{15} \mathrm{~N}$ (Fig. 6D).

\section{Discussion}

Previous rearing experiments performed in the laboratory have indicated particle size, texture and nutrition of diets as important factors, rather than the living status (immobile or moving) for anguillid eel leptocephali (Tanaka et al., 1995, 2003; Wullur et al., 2013; Hagiwara et al., 2014; Butts et al., 2016). Tanaka et al. (1995) first observed that 13 dph leptocephali of the Japanese eel ingested living S-type rotifer Brachionus rotundiformis $(136 \pm 16 \mu \mathrm{m}$ length, $105 \pm 11 \mu \mathrm{m}$ width), but the leptocephali did not survive at all. Many feed candidates were then tried on eel leptocephali, and a slurry-type diet made from shark egg yolk has been the best food so far (Tanaka et al., 2001, 2003). Efforts have also been continued to find living planktons as alternative feed for eel leptocephali. Apart from whether it is digested and assimilated, smaller planktons may be more effectively ingested by the Japanese eel leptocephali (Wullur et al., 2013; Hagiwara et al., 2014). However, no zoo- and/or phytoplanktons in non-processed condition have been confirmed to be digestible and absorbable by eel leptocephali (Tanaka et al., 2003; Wullur et al., 2013; Butts et al., 2016). Our attempts failed to grow the Japanese eel leptocephali by feeding POMs collected in the Western North Pacific. Necrosis of digestive organ occurred in the leptocephali during the feeding trial with large- 


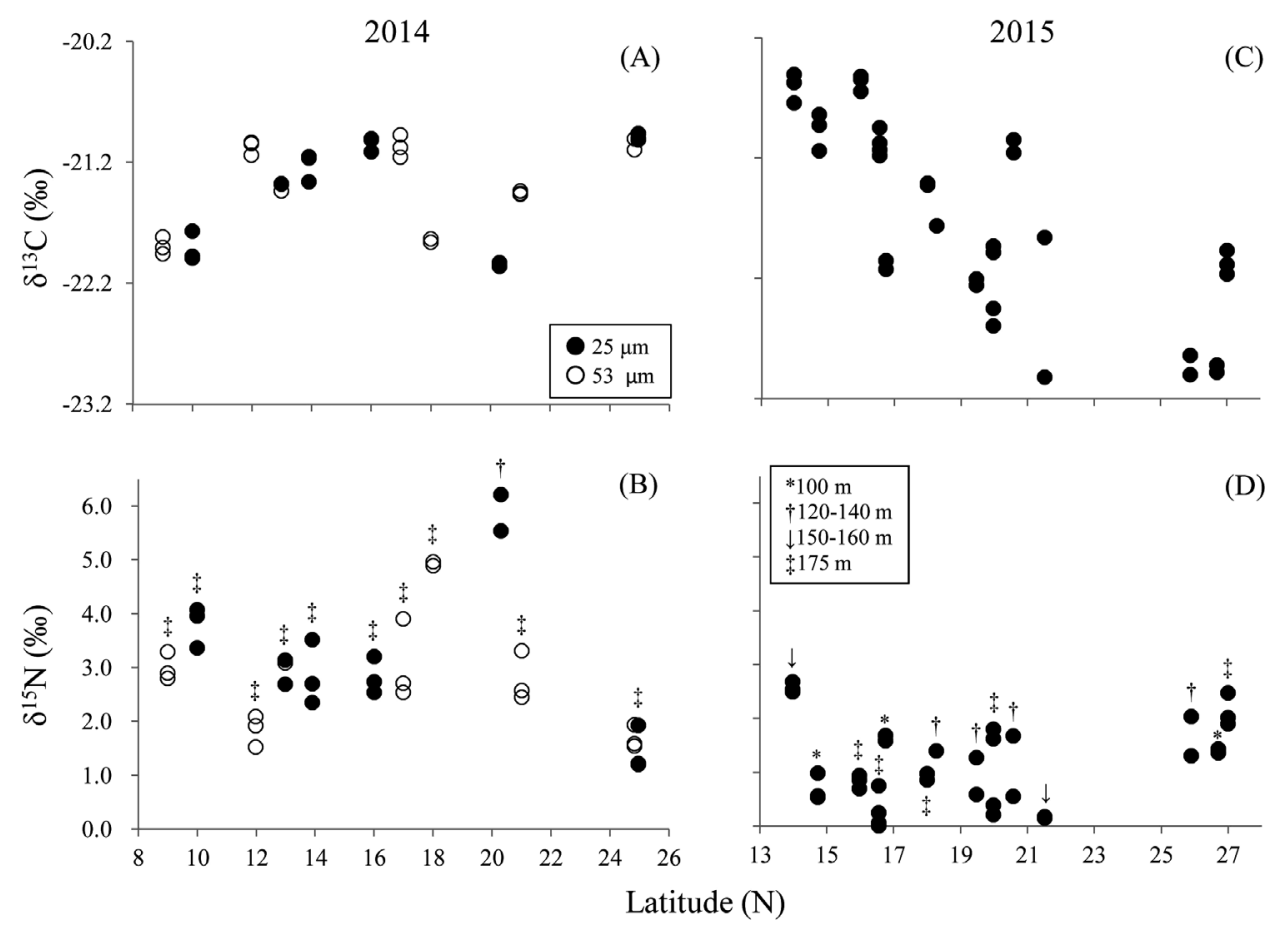

Fig. 6. $\delta^{13} \mathrm{C}(\mathrm{A}, \mathrm{C})$ and $\delta^{15} \mathrm{~N}(\mathrm{~B}, \mathrm{D})$ of POMEW samples plotted against latitude in 2014 (A, B) and 2015 (C, D). Open and closed circles indicate POMEW samples filtered through 53 and $25 \mu \mathrm{m}$ meshes, respectively. Symbols on the plots indicate set depth of the MS net.

size fraction of POM (POMEW350), but no such symptom was observed when feeding smaller fractions (POMEW53 and 25), strongly suggesting that the relatively large zoo- and/or phytoplanktons observed in POMEW350 (Fig. 3) specifically those with hard or pointed body might have seriously damaged the digestive organ of the leptocephali. Although no apparent damage was observed in the digestive organs of leptocephali fed the smaller-size fractions of POMs, very little growth and very low survival were observed. No apparent shift in isotopic signatures of leptocephali reared onboard was also indicative of very little assimilation of the POMs. These indicate that the POMs used in this study are not suitable as feed for the Japanese eel leptocephali.

Recently, Tomoda et al. (2017) found that Alcian-blue stained aggregates (polysaccharides), Coomassie-brilliantblue stained aggregates (proteins) and small spherical particle (2-10 $\mu \mathrm{m}$ in diameter) were common between the environmental water and the gut contents of anguilliform leptocephali, suggesting POM originated from phytoplankton and cyanobacteria to be food sources for the leptocephali. This assumption is consistent with the low trophic position of the eel leptocephali (Otake et al., 1993; Kimura and Tsukamoto, 2006; Chow et al., 2010; Miyazaki et al., 2011; Miller et al., 2013) and the feeding apparatus constrained to feed on small and/or soft particle (Bouilliart et al., 2015). Since the nets (CMS and MS) used in the present study were 60 and $30 \mu \mathrm{m}$ in mesh size, the aggregates and small spherical POMs reported by Tomoda et al. (2017) were not adequately collected and supplied to the leptocephali during the experiments in this study. Development of a method to collect large amount of seawater together with such fine particles and soft aggregates is necessary to elucidate the efficacy of the small POMs as the feed for the Japanese eel leptocephali.
Acknowledgements. We are grateful to captains Y. Terada and S. Toishi and crew members of the R.V. Kaiyo-Maru, the Fisheries Agency of Japan, for their invaluable support during the research cruise. We are indebted to C. Takahashi, T. Kawashima, K. Aoki, K. Yamada, National Research Institute of Fisheries Science, for stable isotope analysis. This work was supported by Fisheries Agency of Japan and Japan Fisheries Research and Education Agency.

\section{References}

Bouilliart M, Tomkiewicz J, Lauesen P, De Kegel B, Adriaens D. 2015. Musculoskeletal anatomy and feeding performance of prefeeding engyodontic larvae of the European eel (Anguilla anguilla). J Anat 227: 325-340.

Butts IAE, Sørensen SR, Politis SN, Tomkiewicz J. 2016. Firstfeeding by European eel larvae: a step towards closing the life cycle in captivity. Aquaculture 464: 451- 458.

Chow S, Kurogi H, Mochioka N, Kaji S, Okazaki M, Tsukamoto K. 2009. Discovery of mature freshwater eels in the open ocean. Fish Sci 75: 257-259.

Chow S, Kurogi H, Katayama S, Ambe D, Okazaki M, Watanabe T, Ichikawa T, Kodama M, Aoyama J, Shinoda A, Watanabe S, Tsukamoto K, Miyazaki S, Kimura S, Yamada Y, Nomura K, Tanaka H, Kazeto Y, Hata K, Handa T, Tawa A, Mochioka N. 2010. Japanese eel Anguilla japonica do not assimilate nutrition during the oceanic spawning migration: evidence from stable isotope analysis. Mar Ecol Prog Ser 402: 233-238.

Furuita H, Murashita K, Matsunari H, Yamamoto T, Nagao J, Nomura K, Tanaka H. 2014. Decreasing dietary lipids improves larval survival and growth of Japanese eel Anguilla japonica. Fish Sci 80: $581-587$.

Govoni J. 2010. Feeding on protists and particulates by the leptocephali of the worm eels Myrophis spp. (Teleostei, 
Anguilliformes, Ophichthidae), and the potential energy contribution of large aloricate protozoa. Sci Mar 74: 339-344.

Hagiwara A, Wullur S, Marcial H.S, Hirai N, Sakakura Y. 2014. Euryhaline rotifer Proales similis as initial live food for rearing fish with small mouth. Aquaculture 432: 470-474.

Hobson KA, Clark RG. 1992. Assessing avian diets using stable isotopes I: turnover of ${ }^{13} \mathrm{C}$ in tissues. Condor 94: 181-188.

Hulet WH. 1978. Structure and functional development of the eel leptocephalus Ariosoma balearicum (DeLa Roche, 1809). Philos Trans $R$ Soc B 252: 107-138.

Itoh H, Mochioka N. 2005. Plankton net designs for sampling mesoplankton in coastal waters. Sci Bull Fac Agr Kyushu Univ 60: 179-186 (in Japanese with English abstract).

Kagawa H, Tanaka H, Ohta H, Okuzawa K, Iinuma N. 1997. Induced ovulation by injection of 17,20b-dihydroxy-4-pregnen-3-one on the artificially matured Japanese eel, with special reference to ovulation tima. Fish Sci 63: 365-637.

Kagawa H, Sakurai Y, Horiuchi R, Kazeto Y, Gen K, Imaizumi H, Masuda Y. 2013. Mechanism of oocyte maturation and ovulation and its application to seed production in the Japanese eel. Fish Physiol Biochem 39: 13-17.

Kimura S, Tsukamoto K, 2006. The salinity front in the North Equatorial Current: a landmark for the spawning migration of the Japanese eel (Anguilla japonica) related to the stock recruitment. Deep-Sea Res II 53: 315-325.

Kurogi H, Okazaki M, Mochioka N, Jinbo T, Hashimoto H, Takahashi M, Tawa A, Aoyama J, Shinoda A, Tsukamoto K, Tanaka H, Gen K, Kazeto Y, Chow S. 2011. First capture of post-spawning female of the Japanese eel Anguilla japonica at the southern West Mariana Ridge. Fish Sci 77: 199-205.

Masuda Y, Oku H, Nomura K, Teruya K, Tanaka H. 2010. A colloidtype diet can be ingested by larvae of the Japanese eel Anguilla japonica. J Fish Technol 2: 99-104 (in Japanese with English abstract).

Miller MJ. 2009. Ecology of anguilliform leptocephali: remarkable transparent fish larvae of the ocean surface layer. Aqua-BioSci Monogr 2: 1-94.

Miller MJ, Otake T, Aoyama J, Wouthuyzen S, Suharit S, Sugeha Y, Tsukamoto K. 2011. Observations of gut contents of leptocephali in the North Equatorial Current and Tomini Bay, Indonesia. Coast Mar Sci 35: 277-288.

Miller MJ, Chikaraishi Y, Ogawa NO, Yamada Y, Tsukamoto K, Ohkouchi N. 2013. A low trophic position of Japanese eel larvae indicates feeding on marine snow. Biol Lett 9: 2012826.
Miyazaki S, Kim H-Y, Zenimoto K, Kitagawa T, Miller MJ, Kimura S. 2011. Stable isotope analysis of two species of anguilliform leptocephali (Anguilla japonica and Ariosoma major) relative to their feeding depth in the North Equatorial Current region. Mar Biol 158: 2555-2564.

Mochioka N, Iwamizu M. 1996. Diet of anguiloid larvae: leptocephali feed selectively on larvacean houses and fecal pellets. Mar Biol 125: 446-452.

Mochioka N, Iwamizu M, Kanda T. 1993. Leptocephalus eel larvae will feed in aquaria. Environ Biol Fish 36: 381-384.

Ohta H, Kagawa H, Tanaka H, Okuzawa K, Hirose K. 1996. Changes in fertilization and hatching rates with time after ovulation induced by 17,20b-dihydroxy-4-pregnen-3-one in the Japanese eel, Anguilla japonica. Aquaculture 139: 291-301.

Otake T. 1996. Fine structure and function of the alimentary canal in leptocephali of the Japanese eel Anguilla japonica. Fish Sci 62: $28-34$.

Otake T, Nogami N, Maruyama K. 1993. Dissolved and particulate organic matter as possible food sources for eel leptocephali. Mar Ecol Prog Ser 92: 27-34.

Tanaka H, Kagawa H, Ohta H, Okuzawa K, Hirose K. 1995. The first report of eel larvae ingesting rotifers. Fish Sci 61: 171-172.

Tanaka H, Kagawa H, Ohta H. 2001. Production of leptocephali of Japanese eel (Anguilla japonica) in captivity. Aquaculture 201: 51-60.

Tanaka H, Kagawa H, Ohta H, Unuma T, Nomura K. 2003. The first production of glass eel in captivity: fish reproductive physiology facilitates great progress in aquaculture. Fish Physiol Biochem 28: 493-497.

Tomoda T, Chow S, Kurogi H, Okazaki M, Ambe D, Furuita H, Matsunari H, Nagai S, Yokouchi K, Nomura K, Tanaka H, Hasegawa D, Inaba N. 2017. Observations of gut contents of anguilliform leptocephali collected in the western North Pacific. Nippon Suisan Gakkaishi (in press) (in Japanese with English abstract).

Tsukamoto K. 2006. Spawning of eels near a seamount. Nature 439: 929.

Tsukamoto K, Chow S, Otake T, Kurogi H, Mochioka N, Miller M.J, Aoyama J, Kimura S, Watanabe S, Yoshinaga T, Shinoda A, Kuroki M, Oya M, Watanabe T, Hata K, Ijiri S, Kazeto Y, Nomura K, Tanaka H. 2011. Oceanic spawning ecology of freshwater eels in the western North Pacific. Nat Commun 2: 179.

Wullur S, Yoshimatsu T, Tanaka H, Ohtani M, Sakakura Y, Kim H-J, Hagiwara A. 2013. Ingestion by Japanese eel Anguilla japonica larvae on various minute zooplanktons. Aquacult Sci 61: 341-347.

Cite this article as: Chow S, Kurogi $\mathrm{H}$, Watanabe S, Matsunari H, Sudo R, Nomura K, Tanaka H, Furuita H, Nishimoto A, Higuchi M, Jinbo T, Tomoda T. 2017. Onboard rearing attempts for the Japanese eel leptocephali using POM-enriched water collected in the Western North Pacific. Aquat. Living Resour. 30: 38 